approach he follows throughout attempts to avoid baffling or terrifying the reader, but I merely found parts of the text irritating, confusing and even patronizing. The text is not helped by the data that do appear; some of the graphs have axes that are labelled with such vague terms as "brain mass" and "body mass" but on which neither the units nor the values are given, and confusion is twice confounded by a legend that reads "data are logarithmic". Nor is the book helped by the line drawings, which are not very life-like and contain some errors: it is the fourth finger of a pterosaur that holds out the wing-tip, not the fifth; and the aerofoil section of a crane-fly wing is corrugated and not the smooth cambered surface that is drawn.

So what are the book's merits? McGowan is at his best with dinosaurs and large tetrapod vertebrates; the chapter "Giants - Modern and Ancient" is readable, interesting and informative on the skeletal design and physiological problems of very large land animals; and his comparisons of large swimming animals from sharks through swordfish to ichthyosaurs are intriguing. And, to be fair, there was no part of the book that I did not enjoy reading - irritations notwithstanding - even though I was left wondering who the intended readership is. This is the sort of book one can give to students to fire up their interest. With its good bibliography, it should lead them into the field before they get down to the nitty-gritty of the implications of scaling.

H. C. Bennet-Clark is in the Department of Zoology, University of Oxford, South Parks Road, Oxford OX1 3PS, UK.

\section{Ins and outs}

\section{P. R. Stanfield}

Handbook of Membrane Channels. Edited by Camillo Peracchia. Academic Press: 1994. Pp. 591. \$120, £92.

An Introduction to Membrane Transport and Bioelectricity. By John H. Byrne and Stanley G. Schultz. Raven: 1994. Pp. 198. $\$ 79.50$ (hbk), $\$ 44$ (pbk).

ION channels are pore-forming proteins that regulate the permeability of cell membranes, including those of intracellular organelles such as endoplasmic reticulum and mitochondria. Channels are venerable in evolutionary terms, occurring in much the same form throughout the animal kingdom; indeed our own potassium-channel subunits will form multimers with those of fruitflies. Some channels are gated by responding to changes in the membrane electric field (more than 100,000 volts per centimetre); others are gated by the binding of ligands, such as neurotransmitters or intracellular substances such as $\mathrm{Ca}^{2+}$, ATP or inositol trisphosphate. Channels allow ionic transfer at rates in excess of 106 ions per second, faster than the turnover number of the fastest enzymes and fast enough to permit the measurement of ion flow through isolated single channels.

The achievement of Neher and Sakmann in making this isolation electrically with patch clamps, coupled with the use of molecular biological techniques to clone, mutate and express ion channels, has led to an explosion of activity. Ten years ago at a meeting of the Society for Neuroscience, an audience of some fifty out of the several thousand attending heard Y. N. Jan give an account of the molecular genetics of the Shaker mutant of the fruitfly, a mutant that lacks one type of potassium channel from its muscle, making it quiver under ether anaesthesia. Although the content of this lecture was at the time difficult for this physiologist to grasp fully, it was obvious that the findings were going to be very important. The same year, Numa's group had sequenced the sodium channels that generate nervous impulses and had already cloned the acetylcholine receptor channels that allow transmission of impulses from nerve to skeletal muscle. This decade of renaissance is now celebrated in the Handbook of Membrane Channels, a book dedicated to the memory of Numa, who helped begin it.

The handbook is wide-ranging, but cannot be said to be comprehensive. The contributions of its many authors are collected into sections, which start with potassium channels and end with the pores formed on fusion of a secretory vesicle with the cell membrane. The writers of the various chapters clearly have the remit of integrating electrophysiological and molecular information, and although many do not pull this off completely, several do. There is, perhaps inevitably, some overlap in content. Some editing might have avoided each of the four chapters on calcium channels beginning with much the same statement about the classification of these channels into L-, T-, N- and P-types. The presence in two consecutive chapters of almost identical but very brief discussions of the cystic fibrosis transmembrane conductance regulator (CFTR) should have been avoided. Indeed, the area surely deserved a chapter of its own. CFTR is of clinical importance, as the mutation (often a simple deletion of a phenylalanine) is so common and still fatal in young adulthood. But the basic science shows that the group of proteins to which CFTR belongs - the ATP-binding cassette proteins - sits on the fence between channels and carriers. Most members of this group do work, actively extruding compounds from cells. Curiously, as Rainer Greger states in his chapter, the $\mathrm{Cl}^{-}$channel formed by CFTR may require ATP hydrolysis to allow downhill movement of $\mathrm{Cl}^{-}$.

Many monographs concerning membrane physiology, aimed at an undergraduate audience, also discuss ion channels while excluding other membrane transport processes. For this reason, the second edition of the book by Byrne and Schultz is to be welcomed. The text is written with clarity and accuracy and is highly readable. The authors' enthusiasm for historical reference is perhaps less well judged; the average 18-year-old biologist is not in my experience turned on by the thoughts of Pliny the Elder. And there are one or two areas of awkwardness. For example, the units for membrane current are introduced as coulombs per $\mathrm{cm}^{2}$ per $\mathrm{hr}$; the circuitry for studying sodium channels using patch-clamp techniques is incorrectly complex; and part of the discussion of the Hodgkin-Huxley equations seems curious. Molecular properties of transporters and voltage-gated channels are touched on; most undergraduate courses may now have integrated this aspect further into the physiology. The best chapters in the Handbook of Membrane Channels show us that all now should.

P. R. Stanfield is in the Department of Cell Physiology and Pharmacology, University of Leicester, PO Box 138, Leicester LE1 9HN, UK.

\section{New in paperback}

The New Catastrophism: The Importance of the Rare Event in Geological History by Derek Ager. Cambridge University Press, $£ 13.95, \$ 24.95$. "His work shares with its predecessor the qualities of originality, readability and seminality. I thoroughly recommend it" (Gordon L. Herries Davies, Nature 365, 115; 1993).

Element of Risk: The Politics of Radon by Leonard A. Cole. Oxford University Press, $\$ 11.95$. "Splendid ... Cole is so deft in analysing the science and politics of radon that it is hard to know whether to laugh or cry (A. Wildavsky, Nature 367. 227; 1994).

Inside NASA: High Technology and Organizational Change in the US Space Program by Howard E. McCurdy. "McCurdy is surely on the right track. His valuable book makes the literature on organizational cultures accessible and reveals new ways to look at high-technology agencies" (David DeVorkin, Nature 363, 407; 1993).

The Evening Star: Venus Observed by Henry S. F. Cooper. Johns Hopkins University Press, $\$ 13.95$. For a review by David Hughes see Nature 364, 683 (1993). 